\title{
IDENTIFYING LOCAL WISDOM IN ELEMENTARY SCHOOL ANTI-CORRUPTION EDUCATION IN MALANG
}

\author{
Pratama Bayu Indra*, Kriyantono Rachmat, Febriani Nufian Susanti \\ Faculty of Social and Political Sciences, University of Brawijaya, Indonesia \\ *E-mail: bayuindrap@ub.ac.id
}

\begin{abstract}
There are very few discussions on instructional communication analysis or known as education communication focusing on anti-corruption and local wisdom. Instructional communication may become preventive solution to prevent corruption. The study discusses local wisdom-based anti-corruption instructional communication. Local wisdom becomes the focus of the study since culture acts as facilitator for internalization of anti-corruption principles. Malang is selected as the setting as the study due to its "arek" tradition. "Arek" tradition is transparent, straightforward and assertive; these are relevant to the principles of anti-corruption. The objective of the study was to identify local wisdom in anti-corruption education. The study was explorative qualitative and the method was focus group discussion. The subjects were teachers in SDN 2 Dinoyo Malang, SD Sang Timur Malang, and SD Insan Amanah Malang. These three elementary schools were selected as the setting because they have different religious orientation. The basis for selecting these schools was to describe different integration of the local wisdom and religious orientation each of the schools have. The findings stated that local wisdom had yet been utilized to facilitate the anticorruption education. Local wisdom was considered as government education embedded in the school activities. Some schools applied the program as a whole while some others were selective towards the program. Based on the findings, anti-corruption principles were embedded through religious and moral values that worked in the society.
\end{abstract}

\section{KEY WORDS}

Policies, education, society, values, communication.

Instructional communication is a type of communication studies focusing on the exchange of verbal and nonverbal messages that occur between teachers and learners (Sprague, 1992). It discusses factors, content, and teaching-learning settings that are communicative for the realization of teaching objectives. Instructional communication is closely related to educational psychology, pedadogy, sociology of education, and counseling (Book, 1989; Sprague, 1992). Instructional communication emphasizes on effective communication efforts in teaching and learning (Sprague, 1992).

Based on instructional communication, one should pay attention to the interaction between teachers and learners instead of doing so to either of them (McCorskey \& McVetta, 1978). Good interaction becomes the determinant factor in achieving learning objectives. Indicators for achievement of learning objectives in instructional communication are cognitive, affective, and psychomotor changes in the learners (Kearney \& Beaty, 1994). Another indicator of effective instructional communication is good relationships between educators and learners both during and outside the teaching and learning process (Powell \& Powell, 2015).

Some instructional communication research shows effective communication between teachers and learners would encourage behavioral change. Powell and Harville (1990) found that there was significant correlation between the teacher clarity, teacher's verbal and nonverbal ability to communicate with the learners and the learning outcomes. In addition, Cayanus (2004) also found that self-disclosure of experience from teachers would result in higher learning motivation and understanding of the learners.

Pragmatism in instructional communication can potentially be used for developing models that can be used to create social change in society (Waldeck, Plax, \& Kearney, 
2010). This obviously takes time. Small changes in teaching and learning can lead to longterm social change (Spector, 2005). Through educational institutions, anti-corruption principles can be internalized to the younger generation (He, 2000; Heilbrunn, 2004). Education becomes a means of preventing corruption. It is an effort to develop awareness about how much damage corruption brings and urgency of eradicating corruption into content in anti-corruption education (Korupsi, 2011).

Anti-corruption education can be one of the instructional communication agendas (Book, 1989; Wibowo, 2013). The roles of educational institutions are not to teach theoretical knowledge, but also moral values (Book, 1989; Dewantara, 2009). Such roles should be facilitated by adequate instructional communication models. Adequate instructional communication models refer to ones having both suitable content and methodology for anticorruption learning.

Corruption has become a cancer for Indonesia. Indonesia Corruption Watch (ICW) revealed that in 2015 the country lost 3.1 trillion because of corruption. The number of people commiting the act of corruptions increases annually.

Some studies discussed instructional communication and corruption. Chi-Ming Lee (2004) suggested that public institutions conducted critical thinking and civic classes as well as provide alternative teaching techniques to strengthen moral education. He stated that the critical thinking, civic classes and alternative teaching techniques that strengthened the existing moral education promoted the improvement of democratic and anti-corruption qualities in the country. Dawson (2011) explained that anti-corruption education was compulsory in Cambodian curriculum; it is taught at every level of education. The number of research in which the instructional communication and corruption become the focus is still relatively limited.

Although some studies show the effectiveness of instructional communication, some others found its shortcoming. Culture becomes one of the causes of instructional communication failure. For example, Sleeter and Grant (1987)'s study showed that cultural differences provided differences in delivery and receiving messages in the learning process. Even some processes were hampered and unsuccessful because of differences in cultural factors. Collier and Powell (1990) found that cultural settings determined the effectiveness of acceptance and the relationship between teachers and learners. Ngai (2015) through his research also mentioned that teachers should adapt more particularly to their students' cultural backgrounds in the teaching and learning process.

Findings of the studies show that cultural context is an inseparable part of instructional communication. There are four things to consider about the cultural context in instructional communication, namely teacher's background, student's background, content and teaching strategy. Teacher and student's background can be related to socio-economic condition, political stand, ethnicity, religion, and race. Content may be related to materials and types of messages the teachers deliver to the students while teaching strategies are related to technique the teachers used in the learning process (Moore, 2014).

Anti-corruption education should take cultural value of the target (audience) into account (Valentina \& Putera, 2013). Integration of culture increases acceptance of anticorruption messages. Local wisdom-based anti-corruption education in Indonesia is a rarity. The researchers found some research related to the topic. Some used the concept of local wisdom and anti-corruption but had yet associated them with instructional communication. For example a study conducted by Suryani (2014) that examined the role of advertising as a medium for anti-corruption education in Baduy society. Tanjung (2013) discussed local wisdom that influenced anti-corruption attitudes in the bureaucracy. There are several studies where the instructional communication models and anti-corruption have adopted moral values into learning content. As an example, Hakim (2012) developed a model combining Islamic values and anti-corruption education curriculum. In the study, Qur'an was the reference for anti-corruption principles. Another example is character-based anticorruption education (Manurung, 2012; Montessori, 2012). These had yet offered clear reference because it did not elaborate what character-based actually was. 
It is nearly impossible to generalize cultural diversity in Indonesia into uniform approach. Each cultural unit has different characteristics that require different approaches as well. Therefore, local wisdom-based anti-corruption instructional communication should be developed. Using local wisdom as the approach is in line with the long-term (2012-2025) and medium-term (2012-2014) National Strategy for Corruption Prevention and Eradication issued in 2012 Based on the elaboration, the researchs are interested in describing local wisdom element in anti-corruption education in elementary school.

Based on the background, the objective of the study is to describe local wisdom in anticorruption education in elementary schools in Malang.

\section{LITERATURE REVIEW}

Instructional Communication. Communication has educational or instructional function, which aims to educate and change one's behavior (Effendy, 2011). Education is right owned by every Indonesian citizen. The 1945 Constitution Article 31 Paragraph (1) states that "every citizen is entitled to education." Every citizen is also entitled to proper education to improve the quality of his/her life. It is also stipulated in the 1945 Constitution Article 28C Paragraph (1) that "every person shall have the right to develop himself or herself through the fulfillment of his or her basic needs, to be entitled to education and to benefit from science and technology, art and culture, to improve the quality of his or her life and for the welfare mankind."

Instructional communication is generally interpreted as the smallest part of education communication. Joseph (2010, p.2) describes instructional communication focusing solely on communication processes that are developed and designed specifically to change behavior of the target to a better direction within a particular community. Instructional communication consists of various variables such as strategy, process, technology and/or a formal system and mastery of concepts in order to change one's behavior towards the better (Yusuf, 2010). Myers mentions that "instructional communication is a unique study, because it stems from three different types of research, namely learning psychology, pedagogy and communication" (as cited in Fasset and Warren, 2010, p.149). Studies on instructional communication focus on communication factors that occur in the learning process.

Beebe dan Timothy (2012, h.1) explain that there are two approaches used in instructional communication, namely rethorical approach and relational approach. Based on the rhetorical perspective, teachers use verbal and non-verbal messages in order to affect or persuade students through materials that can change or improve their attitudes, beliefs, values or behaviors. McCroskey and Richmond explain "the function of rhetorical communication is to persuade others to do what we want/need and think about what we think" (in Beebe and Timothy, 2012, p.2). The focus of the approach is to get specific result using the message from particular source. In teaching and learning context, the desired outcome is process of learning.

McCroskey and Richmond also describe the relational approach as "a relational process between teachers and students that create and use verbal and nonverbal messages to develop relationship between the two " (in Beebe and Timothy, 2012, p.2). The approach emphasizes on affective or emotional responses, then their meaning is created together and disseminated between individuals. Another thing to emphasize in instructional communication is perception of teachers and students about welfare/harmony. The bottom line is the relational approach focuses on teaching, student's experience during the learning process and how students respond the process affectively. It affects the teacher's teaching motivation and the student's learning motivation.

In the study, the researchers adopted Beebe and Timothy (2012)'s rhetorical approach. The researchers used the rhetorical approach to see how teachers persuaded students through instructional communication. The researchers selected the approach in order to describe instructional communication taking place in the elementary schools clearly.

Anti-Corruption Education. Ethimologically-speaking, corruption is derived from Latin word "corruptus" which means a series of cruel image. Corruption is criminal act committed 
together in one or different institutions. Corruption is related to violation of position, power and authority to get personal interest and can potentially cause some loss for an institution (Dahlan, 1982). NACP (National Agency for Corruption Prevention) defines corruption as government apparatus or individual behavior that violates any authority given to him or her or violation of standardized ethics in order to benefit him or herself or other individuals.

Corruption in general consists of the following elements, namely authorities for decision-making relevant for the society, the law related to decision-making (legislation, principle, criteria, procedure), an individual or a group of people seeking for any decision that benefits him/her or them, exchange that benefit decision-maker and other related to the decision, violation of decision-making norm, causing loss for the society (Van Duyne, 2001).

Corruption can be analyzed using three perspectives (Getz, 2006). The first is functional perspective in which corruption refers to an act facilitating and learning exchange of goods, service or other financial transactions. The second perspective is one that considers corruption as interference or violation of decision-making process; it is known as dysfunctional perspective. The last one is normative perspective which means that corruption is violation of normative and correct value (Getz, 2006).

The Ministry of Education of Lithuania (2006) suggests both formal and informal anticorruption education at school. As formal education, elements of anti-corruption should be embedded into general education curriculum whereas, as informal education, the principles of anti-corruption should be embedded in extra-curricular activities, such as civil campaigns, student conferences and other events. The pivotal issue in anti-corruption education is to prevent corruption by introducing what corruption is and how to prevent it through the learning proces. The objective of anticorruption education is to develop value and improve the capacity needed for preparing students against corruption. The final outcomes are awareness towards how much damage corruption causes to the society and the national security of the state, negative attitudes towards corruption and finally, capability to eradicate corruption.

Local Wisdom. Local wisdom is local thought or ideas that contain values, wisdom and good conduct passed between generations (Radmila, 2011). Members of the society obey these values since they are believed to contain the truth. Local wisdom is called adi luhung or good conduct existed in the society that serves as a foundation of positive attitude and action leading towards harmonization. Local wisdom can be established through interaction and is accumulated in various moral teachings (ethics) Javanese use to the following term as reference for ethics or moral value, pepali, unggah-ungguh, suba sita, tata krama, tata susila, sopan santun, budi pekerti, wulang wuruk, pitutur, wejangan, wursita, and wewarah" (Purwadi, 2011, h.8). Local wisdom is spread through various means of communication such as folklore, words of mouth, informal discussion/ gathering, arts (ludruk, ketoprak, wayang or puppet show), folksong, proverbs and sanepa or sinoman (Javanese traditional organization). Local wisdom may be in the form of message (content) or strategy to deliver certain message (method). For example, suggestion to respect other people may be presented using ngoko or krama, two different dialects of Javanese kanguage depending upon the characteristics of the audience as an example of the local wisdom itself.

For Indonesian, the value of adi luhung is stated in the philosophy of the nation, The Five Pillars or Pancasila. Pancasila represents harmony between society in Indonesian. It is the peak of all good values the country has and the culmination of the society's perspective about themselves and their existence as objects and subjects with the universe. Pancasila is the ideal and fundamental condition (the philosophy of thought) of Indonesian people; it is reflected in its 36 points. Pancasila is harmony, the ideology of the nation (Kriyantono, 2012).

\section{METHODS OF RESEARCH}

Research Design. The objective of the study is to describe local wisdom in anticorruption education in elementary schools in Malang, Indonesia. In line with the onjective, the data were in the form of description related to local wisdom of Malang (Kriyantono, 2006; Neuman, 2013). The data are not in the form of numbers for statistical analysis (Neuman, 
2013). Thus, the approach of the study was constructivism and the design was explorative qualitative.

Reseach Methodology. The research methodology was Focus Group Discussion and intensive interview. Wimmer \& Dominick (2011) and Kriyantono (2006) mentioned that FGD and intensive interview functioned as both methodology and data collection technique. Through the Focus Group Discussion, researchers explore ideas and information as well as obtain some data related to perception, opinion, point-of-view, trust, response and attitude towards an issue, situation or product (Krueger, 1988). In the study, FGD was used to identify the local wisdom of Malang in elementary school anti corruption education in Malang. The researchers described the teachers' value, attitude and perspective towards the local wisdom related to anti-corruption. The intensive interview was the follow-up for the FGD. Some participants of the FGD were interviewed to obtain more elaborated piece of information.

Subject of the Study. The subjects of the stdudy were three elementary schools in Malang, namely SDN 2 Dinoyo, SD Sang Timur, and SD Insan Amanah. The schools were selected because each of them had different education orientation background. SDN 2 Dinoyo is public school, SD Sang Timur is a Catholic school, and SD Insan Amanah is an Islamic school. These different backgrounds were then related to their existence in Malang. It was expected the integration between the religious orientation of these schools and the characteristics of the native of Malang gained some insight about local wisdom-based anticorruption education.

Data Collection Technique. There were two types of data collection in the study. The first data collection technique was Focus Group Discussion (FGD) for the teachers in SDN 2 Dinoyo, SD Sang Timur, and SD Insan Amanah. The FGD was conducted in all three elementary schools. After conducting FGD, the researchers proceeded to in-depth / intensive interview. Some FGD participants were interviewed in the schools were they were working. The interviewees were selected based on the answer they gave during the FGD. The researchers would interview FGD participants who gave very little response or whose response was unclear. The purposes of the in-depth interview were to gain some more information in general and explore the interviewees' ideas further in particular.

Data Analysis Technique. The data analysis technique was thematic analysis (Neuman, 2013). Thematic analysis is in line with the objective of the study, identifying local wisdom-based anti-corruption education in instructional communication. The conversation taking place in the Focus Group Discussion (FGD) and the result of the in-depth interview were transcribed into texts. The Focus Group Discussion transcription was then analyzed to find similar themes from the entire data. The researchers would make some categories and classify the data based on these categories.

\section{RESULTS AND DISCUSSION}

The settings of the study were three elementary schools with different background and characteristics. SD Negeri Dinoyo is a public elementary school. SD IT Insan Amanah and SD Sang Timur are Islamic and Christian schools.

Despite having different background and characteristics, these three schools had the same perception about corruption. These schools considered stealing or taking other people's belonging is the example of corruption. Other examples were late coming, did not submit assignment, cheating and being irresponsible. In conclusion, they associated corruption to dishonesty.

The schools also had similar methods to apply the anti-corruption education. Formal and informal methods, practice or theory were the methods they use to develop the students' awareness against corruption. In SDIT Insan Amanah Malang, the teachers always asked their students questions related to praying; it is expected that such question develop the students' honesty. To validate the students' responses, the teachers communicated with the parents thorugh SMS gateway and whatsapp. SDIT Insan Amanah Malang also conducted various events and activities of which purpose was to teach what honesty was. One of the 
activities was Amal Jum'at where the students donated some money every Friday and reported how much money they collected without the teachers' help. Besides that, the students are accustomed of reporting to their teachers whenever they found unattended goods including money. Teachers would then make some notification. Those who owned them should contact their teachers to collect their lost items.

SDK Sang Timur taught honesty through kantin kejujuran, a self-service school canteen. The objective of kantin kejujuran is to develop students' honesty and responsibility. Another activity the school had was donation. Students donated parts of their weekly allowance every Friday. Without help of their teachers, the students took a donation box, put it in their classroom and at the end of the day returned it to their teachers.

SDN 2 Dinoyo Malang also had kantin kejujuran. When there was violation, the teachers would directly explain how important honesty was. The teachers also reminded the students that they should be honest in any occasion, for example while they were doing assignment, homework or borrowing stationery from their classmates. When a student was caught red handed, the teachers would give him or her some warning and advice. Another activity to develop the student's honesty was amal Jumat. Similar to one SDIT Insan Amanah Malang conducted, SDN 2 Dinoyo Malang donated some money every Friday. The students collected their donation and counted how much money they donated under the teachers' supervision.

Due to their background and characteristics, the schools applied different methods during the implementation of anti-corruption education. To develop their students' responsibility, SDIT Insan Amanah Malang conducted an activity called Bina Sholat for Grade 1 to Grade VI students. During the activities, the teachers informed students that there was strong correlation between prayer and daily activities. Besides that, the teachers encourage students to help each others and be honest, for example reporting unattended good to the teachers. To develop their students'honesty, the teachers introduced the wisdom of the Prophets and khulafaur rasyidin through story, video or movies. The teachers emphasized that honesty was integral part of Islam and God always knows and watches upon everyone. In conclusion, SD IT Insan Amanah used Islamic teaching as the foundation to develop the students' honesty and for the anti-corruption education.

Related to the local wisdom of Malang, all of the teachers agreed upon adopting the local culture for the learning activities. However, according to the teachers from SDIT Insan Amanah, they would select certain local wisdom that was not against Islamic teaching or syaria.

SDK Sang Timur developed their students' characteristics and moral value through a subject called pendidikan Ke-Sang Timur-an or Bina Iman. During Bina Iman program, the students learned Catholic teaching through movies. Having finished watching the movie, the students reported what their take out was. Anti-corruption education was implemented through two main principles, caring and respect (students were taught not to hurt or humiliate other people). The concept of discipline and responsibility was introduced through constant reminder to be punctual and attend the class on-time. Several students whom the teachers thought were the most responsible ones were awarded the title "Polisi Sekolah." Such reward was given to encourage other students to be honest and responsible.

SDK Sang Timur participated in the annual mask dance festival as an attempt to preserve the local culture. In addition, the school always greeted their guests with traditional dancing performance.

As heterogenous school, SDN Dinoyo 2 Malang had its own methods to conduct anticorruption education in the school. The first was to teach the anti-corruption principles in the classroom (formal education). Prior to the implementation of the 2013 Curriculum, ethics and anticorruption education is incorporated and integrated into Civics Education lesson. In the 2013 Curriculum 2013, these principles should be introduced in every subject. The pivotal personality traits the teachers should introduce were honesty, courtesy, and characterbuilding. The school principal also emphasized the importance of examples to the students regularly. The school also asked parents to teach the students to be honest, polite and responsible at home. 
SDN Dinoyo 2 introduced the local culture of Malang through both theory and practice. The students had dance class where they learned the mask dance of Malang and other traditional dancing from Malang. Topeng Malangan, traditional mask of Malang and lantern were two cultural items decorating all corners of the school. The school did not introduce the local cultural aspects that are against ethics and honesty such as bahasa walikan.

In conclusion, the three schools agreed that honesty, responsibility and discipline were the keys of the anti-corruption education. These schools introduced the concepts through formal and informal education or theory and practice. The examples were kantin kejujuran, weekly donation, and introducing moral values and ethics through stories, video or movie.

At the same time, each school had their own methods to introduce the anti-corruption principles to the students. SD IT Insan Amanah used Islamic teachings as the reference while SDK Sang Timur emphasized caring and respect through pelajaran ke-Sang Timuran or Bina Iman. SDN 2 Dinoyo adopted the 2013 Curriculum for character-building because the school was a heterogenous one.

These three schools also have their own programs to introduce the culture to the students. SD IT Insan Amanah adopted the local culture that reflected Islamic teaching. SDK Sang Timur introduced the local culture by participating in the cultural festivals and SDN 2 Dinoyo Malang conducted class on the traditional mask dance of Malang and other traditional dance from the area. The school also introduced bahasa walikan khas Malang, the local language of Malang but the use of the language at school was prohibited.

\section{DISCUSSION OF RESULTS}

Based on the findings, the schools had the same perspective about corruption. Corruption is taking other people's right. Corruption is not limited to material items but also non-material ones. The examples of material items are goods, money or objects belong to others while the non-material ones are time, job and rewards. The instance of the act of corruption related to time is coming to school late and violation of rights. Cheating or plagiarism is another example. Abandonment and under appreciaton are two examples of the act of corruption related to rewards.

The schools also put emphasis on honesty since it is considered as preventive measure against corruption. Corruption is associated to dishonesty. Lying may become the trigger of corruption because a lie leads to another. It is expected that the students will fight against corruption in their adulthood when they have thorough understanding on the concept of honesty.

Each school has their own methods to introduce the concept of honesty to the students. SDIT Insan Amanah used Islamic teaching as their main reference. The school also use the national or regional curriculum as reference but they should make some adaptation in order that Islamic teaching is represented in the curriculum. The school is not going to use or alter pedagogical concepts that do not represent Islamic teaching. At the opposite, SD Negeri Dinoyo 2 adopts the national curriculum as a whole. It is unable to make adjustment since the school is one of the instruments of the national education. SD Kristen Sang Timur combines the national curriculum, catholic teaching and moral education specifically designed by the foundation that owns the school to introduce the principles of anti-corruption.

The reference the schools used is dictated by the schools' visions and their students. All students of SDIT Insan Amanah are Moslem and have good economic situation. SD Negeri Dinoyo 2 and SD Kristen Sang Timur have more heterogenous students. As public school, SD Negeri Dinoyo 2 should accept anyone regarless of his or her background. The same practice occurs in SD Kristen Sang Timur because one of the primary targets of the school is students coming from low economic family.

The different orientation and students has implications towards the methods the school use to introduce the concept of honesty in each school. The concept is commonly taught in the formal situations (in the classroom) as well as outside the classroom. In the classroom, $S D$ Negeri Dinoyo 2 students embedded the concept in each classroom activities. When 
there is violation, the teachers immediately correct the behavior. Similar thing happens in the otwer two schools. The teachers at SD Kristen Sang Timur use humor as one medium to convey the importance of honesty. Another method is to use alias (animated character) to give examples about theonality traits to the students.

Besides through formal teaching, the teachers used other teaching media for the anticorruption education. SDIT Insan Amanah and SD Kristen Sang Timur use video downloaded from the internet. SDIT Insan Amanah allocated specific time for students to watch video about the Prophets, twice a month as the substitution for the flag ceremony. Different from SDIT Insan Amanah, the students of SD Kristen Sang Timur watch the videos during pelajaran Ke-Sang Timur-an class.

The content of the video in SDIT Insan Amanah and SD Kristen Sang Timur is not the same obviously. SDIT Insan Amanah played video/movies about the Prophets and their companionship. The videos/ movies are then related to Islamic teaching. In other words, the video helps the students to develop devotion towards Islam. On the other hand, SD Kristen Sang Timur does not have specific theme for the video they play for the students. Some of the videos describe daily activities. Having watched the video, the teachers ask the students to make comparison between the content of the video and Catholic teaching.

Unlike the other two elementary schools, SD Negeri Dinoyo 2 does not use video as teaching media. Character-building material (moral education) is embedded in each classroom activity. The school does not allocate specific time to discuss materials related to the topic either.

In line with their visions, the schools implement different types of rewards and punishment. Emphasizing on Islamic teaching, SDIT Insan Amanah introduce the concept of merit and sin. SD Kristen Sang Timur introduce cause-effect theory which means everything has consequences and one's decision is going to affect other people (positive and negative implication). Furthermore, SD Negeri Dinoyo 2 refers to the law, regulations and social value for their rewards and punishment system.

Furthermore, the schools have specific subject to introduce the concept of honesty to their students. East Sangria's Christian school instills honesty values through the education of Kesangtimuran. SD Kristen Sang Timur introduced the concept through a subject called pelajaran Kesangtimuran. The founder of Sang Timur Foundation, Sister Clara Fey inspired the class. The class discusses her live, activities and good conduct. In contrast, SDIT Insan Amanah has a subject called Bina Shalat of which purpose is to improve the students' devotion towards their religion. The teachers develop the students' discipline to pray 5 times a day. When there is violation, the teachers would discuss things with the students violating the rules. According to the school, prayer helps students to avoid any wrongdoing. SD Negeri Dinoyo 2 does not have any specific subject for incharacter-building. The concept of honesty and other positive traits were introduced in religion and civic classes. It has $5 \mathrm{~S}$ concept which stands for Senyum, Salam, Sapa, Sopan, and Santun. The concept basically reminds students to be polite.

The students are motivated to develop their honesty outside the class through several activities. SD Negeri Dinoyo 2 and SD Insan Amanah conducted donation every Friday in which the students collected some money as donation without their teachers' supervision. The students' honesty is evaluated during the charitable activity. SD Kristen Sang Timur does not conduct such activity every week; instead, the students and the teachers collected some money when one of the teachers or students is sick or hospitalized.

Another method to develop the students' honesty is kantin kejujuran. Both SD Negeri Dinoyo 2 and SD Kristen Sang Timur have one. In the beginning, there were some loss but the students have been getting accustomed of the system now. As an addition, the teachers constantly remind students how kantin kejujuran works and emphasize on the significance of honesty. Everything runs smoothly now. SDIT Insan Amanah does not have kantin kejujuran.

In relation to the local culture, each of the schools has different perspective. SD Negeri Dinoyo 2 thinks it is vital to preserve the local culture. They decorated the schools with local handicrafts such as traditional mask and lantern as suggested by the regional government. The school also has traditional dance class to introduce the students to the local culture. 
Similar to SD Negeri Dinoyo 2, SD Kristen Sang Timur also decorate the school with the local handicraft and conduct traditional dancing class. In addition, the school participates in the annual traditional mask dance festival conducted by the government of Malang. At last, the school greets their guests with traditional dancing performance.

At the opposite, SDIT Insan Amanah perceived the local culture of Malang such as mask and lantern against Islamic teaching. Therefore, the school did not encourage preservation of the local culture. In order to meet the government's regulation, the school modified the cultural aspects to match Islamic teaching. Every cultural aspects introduced to the students should represent Islamic teaching.

Even though the three schools have different perspective about the local wisdom of Malang, they have the same idea towards the correlation between culture and honesty. $S D$ Negeri Dinoyo 2, SD Kristen Sang Timur, and SDIT Insan Amanah unanimously stated that there is not any correlation between the local wisdom and character-building (honesty). These two are separated entities. All three schools do not encourage the use of Javanese language at schools and strictly prohibit the use of Javanese slang. In terms of Bahasa Walikan, the schools argued that the language is not relevant to the current society because it is the language used as the secret code among Indonesian to deceive the Dutch.

The schools realize that family members and environment affect the students' characteristics. Hence, each of them has their own methods to develop relationship between the school and the parents. SD Negeri Dinoyo 2 introduce their 5S concept to the parents who come to the school. The principal encourage the students to apply the concept at home because parents should set good example for their children. Besides that, the school directly involves the parents to solve students' problems. When there is violation, the school will invite the parents for discussion.

SDIT Insan Amanah also involves parents in dealing with the students' problems. The school even use specific applications to communicate with the students' parents or legal guardian. The first is sms gateway that the school uses to send some announcement and notification to the parents. The parents can also use the application if they have some suggestion or criticisms towards the school. The second is whatsapp. Each class teacher creates whatsapp group where he or she communicates with the parents. He or she can also directly send message to each parent. The objective of the whatsapp group is to facilitate better communication between the teachers and the parents. When students have issues at school, the teacher will directly contact the parents using either or both applications asking them to come to the school. The teachers also use the applications to make clarification or verification to the parents.

Different from SD Negeri Dinoyo 2 and SDIT Insan Amanah, SD Kristen Sang Timur does not directly involve the parents whenever there is violation by students. For minor issue, the teachers call on the students without informing their parents. The relationship between the school and the parents is limited to the class committee which consists of the students' parents' representatives and the school committee (Parent Teacher Association).

Based on the elaboration, it is concluded that the local wisdom of Malang has yet been embedded in the anti-corruption education in the three elementary schools. The schools assumed that there is not any correlation between culture and anti-corruption education. These schools used religious teaching and good moral conduct as the bases for their anticorruption education.

\section{CONCLUSION}

Based on the statement of the problem, how local wisdom is embedded into elementary school anti-corruption education in Malang, the conclusion is that local wisdom as local identity is embeeded into the teaching and learning process as well as extracurricular activities such as celebrating religious holiday. The teachers also introduce the local wisdom to the students by making integration between the local culture and learning methods, for instance "bahasa walikan," local language of Malang and other familiar culture aspects as an ice-breaker. 
Teachers have authority to introduce the local wisdom to their students, and also select which elements of the local wisdom suitable for their student's need and condition. In the public and Islamic schools, teachers introduce elements of local wisdom that meet the orientation of the schools. The teachers have been able to introduce cultural aspect and explain cultural development to their students. It is concluded that there is correlation between the content of local wisdom being taught and vision or mission of the schools.

The finding revealed that these schools have yet utilized local wisdom for anticorruption education. These schools perceive local wisdom as not more than government applied in school activities. Some schools take it as whole while some others are selective towards the program. The anti-corruption principles are embedded through religious and moral values exist in the society.

\section{REFERENCES}

1. Book, C. L. (1989). Communication education: Pedagogical content knowledge needed. Communication Education, 38(4), 315-321.

2. Cayanus, J. L. (2004). Effective instructional practice: Using teacher self-disclosure as an instructional tool. Communication Teacher, 18(1), 6-9. doi: 10.1080/1740462032000142095

3. Chi-Ming Lee. (2004). Changes and challenges for moral education in taiwan. Journal of Moral Education, 33(4), 575-595. doi: 10.1080/0305724042000315635

4. Collier, M. J., \& Powell, R. (1990). Ethnicity, instructional communication and classroom systems. Communication Quarterly, 38(4), 334-349. doi: 10.1080/01463379009369771

5. Dahlan, M. (1982). Pengawasan dari kacamata yang diawasi. Background paper ii, dalam masalah-masalah peningkatan kemampuan aparat pengawasan- himpunan bahan bahan sarasehan pengawasan pembangunan. Menteri Negara Pengawasan Pembangunan Dan Lingkungan Hidup. geography and government.

6. Dawson, W. (2011). Supplementary education in cambodia. IIAS Newsletter, 18-19.

7. Dewantara, K. H. (2009). Menuju manusia merdeka. Yogyakarta: Leutika.

8. Effendy, O. U. (2011). Ilmu komunikasi: teori dan prakteknya. Bandung: Remaja Rosdakarya

9. Getz, K. A. (2006). The effectiveness of global prohibition regimes : Corruption and the antibribery convention. Business Societ, 45(254).

10. Hakim, L. (2012). Model integrasi pendidikan anti korupsi dalam kurikulum pendidikan islam. Jurnal Pendidikan Agama Islam Ta'lim, 10.

11. He, Z. (2000). Corruption and anti-corruption in reform china. Communist and PostCommunist Studies, 33(2), 243-270.

12. Heilbrunn, J. R. (2004). Anti-corruption commissions: Panacea or real medicine to fight corruption. World Bank Institute, Washington, DC. The Many Faces of Corruption.

13. Kearney, P., \& Beaty, M. J. (1994). Measures of instructional communication. In R. B. Rubin, P. Palmgreen \& H. E. Sypher (Eds.), Communication research measures: A sourcebook (pp. 7-20). New York: Guilford.

14. Korupsi, T. P. B. P. A. (2011). Buku pendidikan anti korupsi untuk perguruan tinggi (M. E. S. Nanang T. Puspito, Indah Sri Utari, Yusuf Kurniadi Ed.). Jakarta: Kementerian Pendidikan dan Kebudayaan RI.

15. Kriyantono, R. (2006). Teknik praktis riset komunikasi: Disertai contoh praktis riset media, public relations, advertising, komunikasi organisasi, komunikasi pemasaran. Jakarta: Kencana.

16. Kriyantono, R. (2012). Etika dan filsafat ilmu komunikasi. Malang: UB Press.

17. Krueger, R. A. (1988). Focus groups: A practical guide for applied research. California: Sage Publications.

18. Manurung, R. T. (2012). Pendidikan antikorupsi sebagai satuan pembelajaran berkarakter dan humanistik. Jurnal Sosioteknologi(Vol 11, No 27 (2012)), 227-239. 
19. McCorskey, J. C., \& McVetta, R. W. (1978). Classroom seating arrangements: Instructional communication theory versus student preferences. Communication Education, 27(2), 99-111. doi: 10.1080/03634527809378281

20. Ministry of Education and Science of the Republic of Lithuania. (2006). Anti-Corruption Education At School: Methodical material for general and higher education schools. Lithuania: Modern Didactic Centre, Garnelis Publishing.

21. Montessori, M. (2012). Pendidikan antikorupsi sebagai pendidikan karakter di sekolah. Jurnal Demokrasi, 11(1).

22. Moore, K. D. (2014). Effective instructional strategies: From theory to practice. London: Sage Publications.

23. Myers, S. A. (2010). Instructional communications: the emergency of a field. In D.L. Fasset, \& J.T. Warren, The sage handbook of communication and instruction (h.149159). Los Angels: Sage Publications

24. Neuman, W. L. (2013). Metode penelitian sosial: Pendekatan kualitatif dan kuantitatif. Jakarta: Indeks.

25. Ngai, P. (2015). The impact of teachers' communication approach on children's cocultural adaptation. Journal of Intercultural Communication(37).

26. Powell, R. G., \& Harville, B. (1990). The effects of teacher immediacy and clarity on instructional outcomes: An intercultural assessment. Communication Education, 39(4), 369-379. doi: 10.1080/03634529009378816

27. Powell, R. G., \& Powell, D. L. (2015). Classroom communication and diversity: Enhancing instructional practice. London: Routledge.

28. Purwadi (2011). Etika komunikasi dalam budaya jawa. Jurnal IImu Komunikasi, 9(3).h. 139-249. ISSN 1693-3029

29. Radmila, S. (2011). Kearifan Lokal : Benteng Kerukunan. Jakarta: PT. Gading Inti Prima.

30. Sleeter, C., \& Grant, C. (1987). An analysis of multicultural education in the united states. Harvard Educational Review, 57(4), 421-445.

31. Spector, B. I. (2005). Fighting corruption in developing countries: Strategies and analysis: Kumarian Press Bloomfield, CT.

32. Sprague, J. (1992). Expanding the research agenda for instructional communication: Raising some unasked questions. Communication Education, 41(1), 1-25.

33. Suryani, I. (2014). Menggali keindahan alam dan kearifan lokal suku baduy (studi kasus pada acara feature dokumenter "indonesia bagus" di stasiun televisi net. Tv). Musãwa Jurnal Studi Gender dan Islam, 13(2), 179-194.

34. Tanjung, I. (2013). Kearifan lokal dan pemberantasan korupsi dalam birokrasi. MIMBAR (Jurnal Sosial dan Pembangunan), 29(1), 101-110.

35. Valentina, T. R., \& Putera, R. E. (2013). Buildng the local elements of national anti corruption integrity sistem in west sumatera. International Journal of Administrative Science \& Organization, 20(2), 78-84.

36. Van Duyne, P. (2001). Will 'Caligula' go transparent?. Forum on crime and society, 1(1), 74-76

37. Waldeck, J. H., Plax, T. G., \& Kearney, P. (2010). Philosopical and methodological foundations of instructional communication. In D. L. Fassett \& J. T. Warren (Eds.), The sage handbook of communication and instruction. London: SAGE Publicantions.

38. Wibowo, A. (2013). Pendidikan anti korupsi di sekolah. Yogyakarta: Pustaka Pelajar.

39. Wimmer, R.D \& Joseph R.D. (2011). Mass media research: An Introduction. (9thedition). USA: Wadsworth

40. Yusuf, P. M. (2010). Komunikasi Instruksional: teori dan praktet. Jakarta: PT. Bumi Aksara. 